\title{
Sequential granite emplacement: a structural study of the late Variscan Strzelin intrusion, SW Poland
}

\author{
Teresa Oberc-Dziedzic $\cdot$ Ryszard Kryza $\cdot$ \\ Christian Pin $\cdot$ Stanisław Madej
}

Received: 27 June 2012/ Accepted: 24 January 2013/Published online: 3 March 2013

(C) The Author(s) 2013. This article is published with open access at Springerlink.com

\begin{abstract}
The Strzelin Massif in SW Poland (Central European Variscides) records a protracted igneous evolution, with three main magmatic stages: (1) tonalitic I, (2) granodioritic and (3) tonalitic II/granitic. In the northern part of this Massif, the Strzelin intrusion proper comprises three successively emplaced rock types: a medium-grained biotite granite (303 $\pm 2 \mathrm{Ma}$ ), a fine-grained biotite granite $(283 \pm 8 \mathrm{Ma})$ and a fine-grained biotite-muscovite granite; based on field evidence, the third variety postdates both types of the biotite granites. The structural data from the three granites, including their parallel, approximately E-W striking and steeply dipping lithological contacts and ENEWSW trending subhorizontal magmatic lineations, suggest that the emplacement of all three successive granite varieties was controlled by an active, long-lived strike-slip fault, striking ESE-WNW, with a dextral sense of movement. After the emplacement of the youngest biotitemuscovite granite, the intrusion underwent brittle extension which produced "Q joints" striking NNW-SSE to N-S and dipping at $55-70^{\circ} \mathrm{WSW}$ to $\mathrm{W}$, and showing evidence of broadly $\mathrm{N}-\mathrm{S}$ directed sinistral displacements. The
\end{abstract}

From 1920 to 1922 , Hans Cloos published his pioneering studies on granite tectonics, based on his investigations initiated in the Strzelin Massif (NE part of the Bohemian Massif). The authors of this paper wish to commemorate the 90th anniversary of the prominent Hans Cloos' publications, presenting results of their recent research in the Strzelin intrusion.

T. Oberc-Dziedzic $\cdot$ R. Kryza $(\bowtie) \cdot S$. Madej Institute of Geological Sciences, University of Wrocław, Plac M. Borna 9, 50-204 Wrocław, Poland

e-mail: ryszard.kryza@ing.uni.wroc.pl

C. Pin

Département de Géologie, CNRS, Université Blaise Pascal, 5 rue Kessler, 63038 Clermont-Ferrand Cedex, France structural observations, supported by new geochronological data, indicate that the internal structure of the composite granitoid intrusion, including the faint magmatic foliation and lineation, formed in a long-lived strike-slip setting, different from the subsequent, post-emplacement extensional tectonics that controlled the development of brittle structures.

Keywords Granite tectonics - Variscan granitoids . Strzelin Massif · Hans Cloos

\section{Introduction}

Extensive granitoid plutonism is a distinct feature of the European Variscides (Fig. 1a). In the Bohemian Massif in the eastern part of the Variscan belt (Fig. 1b), the igneous activity continued from the late Devonian to early Permian and produced granitoid magmas generated from various sources and, consequently, differing in their petrographic and geochemical characteristics (Finger et al. 1997). The abundant granite plutons in Lower Silesia in the NE part of the Bohemian Massif were studied nearly a century ago by Hans Cloos, and it was where he developed his classical concept of "granite tectonics" (Cloos 1920, 1921, 1922a, b, 1925).

Nearly one hundred years after Cloos' basic works, the knowledge of the internal structures of granite intrusions and their interpretations have considerably developed, though Cloos' main ideas seem to remain valid. The Strzelin intrusion in the Sudetes (Fig. 1c) was the site of Cloos' original investigations in the early 1920s. Since that time, this intrusion has been intensely excavated in large quarries, making it more accessible for new investigations. In this paper, we present structural observations from the 

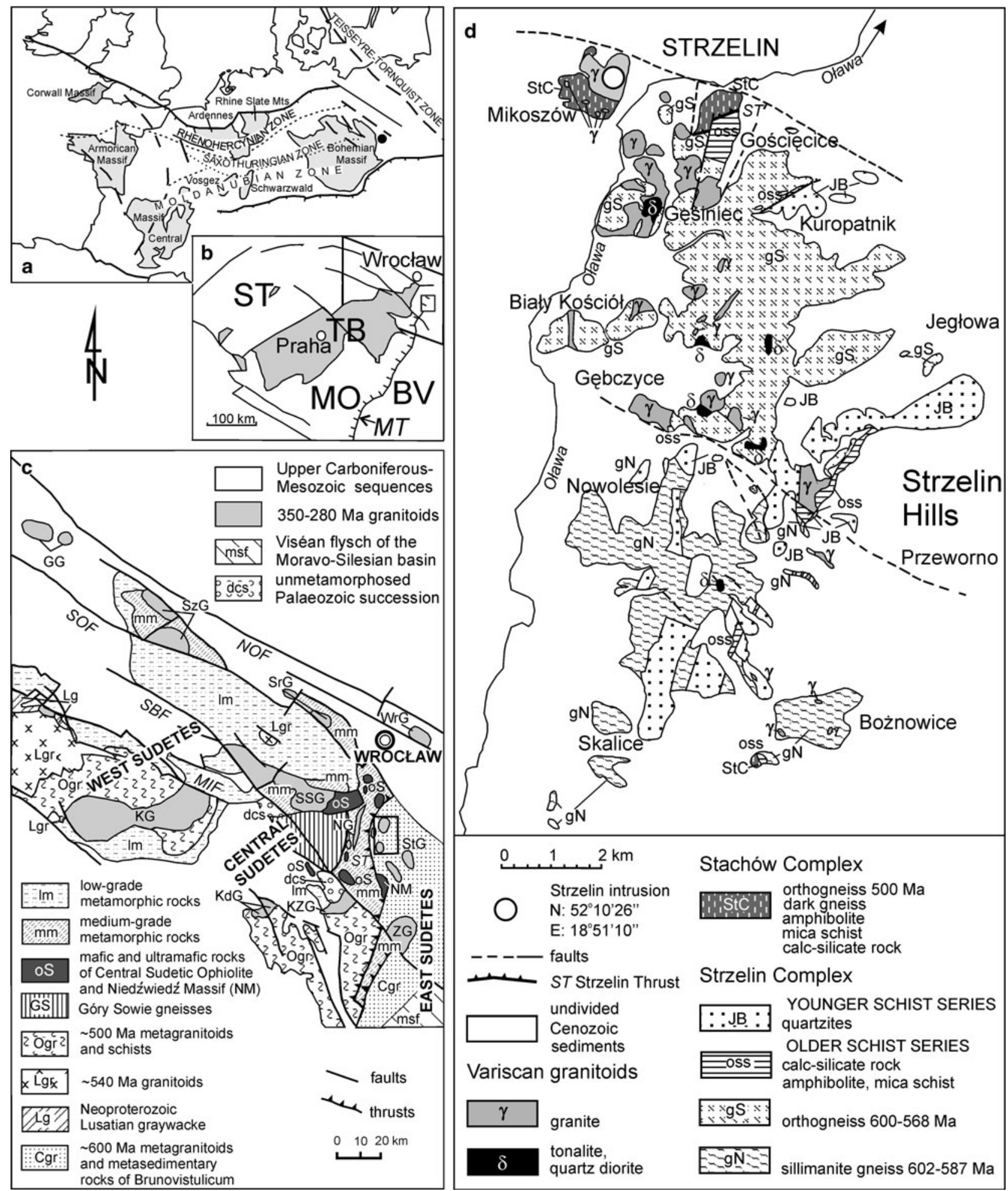

Fig. 1 a Position (black point) of the study area in the Bohemian Massif and in the European Variscides. b Sketch map of the Bohemian Massif (ST-Saxothuringian, TB-Teplá-Barrandian, MO-Moldanubian zones, after Franke 2012) and Brunovistulicum (BV); MT-Moldanubian Thrust; large and small quadrangles show of the location of the Sudetes and the Strzelin Massif, respectively. c Variscan granitoids: Odra Fault Zone: GG-Gubin, SrG-Środa Śląska, SzG-Szprotawa, WrG-Wrocław;
Fore-Sudetic Block: NG-Niemcza, SSG-Strzegom-Sobótka, StGStrzelin, ZG-Žulova; Sudetes: KdG-Kudowa, KG-Karkonosze, KZG-Kłodzko-Złoty Stok. Faults: MIF-Main Intra-Sudetic Fault, SMF-Sudetic Marginal Fault, SOF-Southern Odra Fault, NOFNorthern Odra Fault; thrusts: NT-Nyznerov Thrust, ST-Strzelin Thrust. Rectangle shows the position of the Strzelin Massif. d Geological map of the eastern part of the Strzelin Massif (after Oberc et al. 1988) 
Fig. 2 a The Strzelin I quarry viewed from the south. The quarry is $\sim 600 \mathrm{~m}$ long, $200 \mathrm{~m}$ wide and $120 \mathrm{~m}$ deep. Q, S, L joints (symbols after Cloos 1921, 1922); Bt-Ms-finegrained biotite-muscovite. $\mathbf{b}$, c Structural elements of the Strzelin granites, view from SSW (after Cloos 1921, Fig. 1): b Scheme of joints: Q-cross joints, S-longitudinal joints, L-flat-lying joints, $\mathrm{K}$ "artificial" joints; Glithostatic pressure, D—side pressure during solidification of granite, $\mathrm{F}$-parallel orientation of minerals (streaking). c Block of granite showing linear structures and dyke conformable with the Q joints

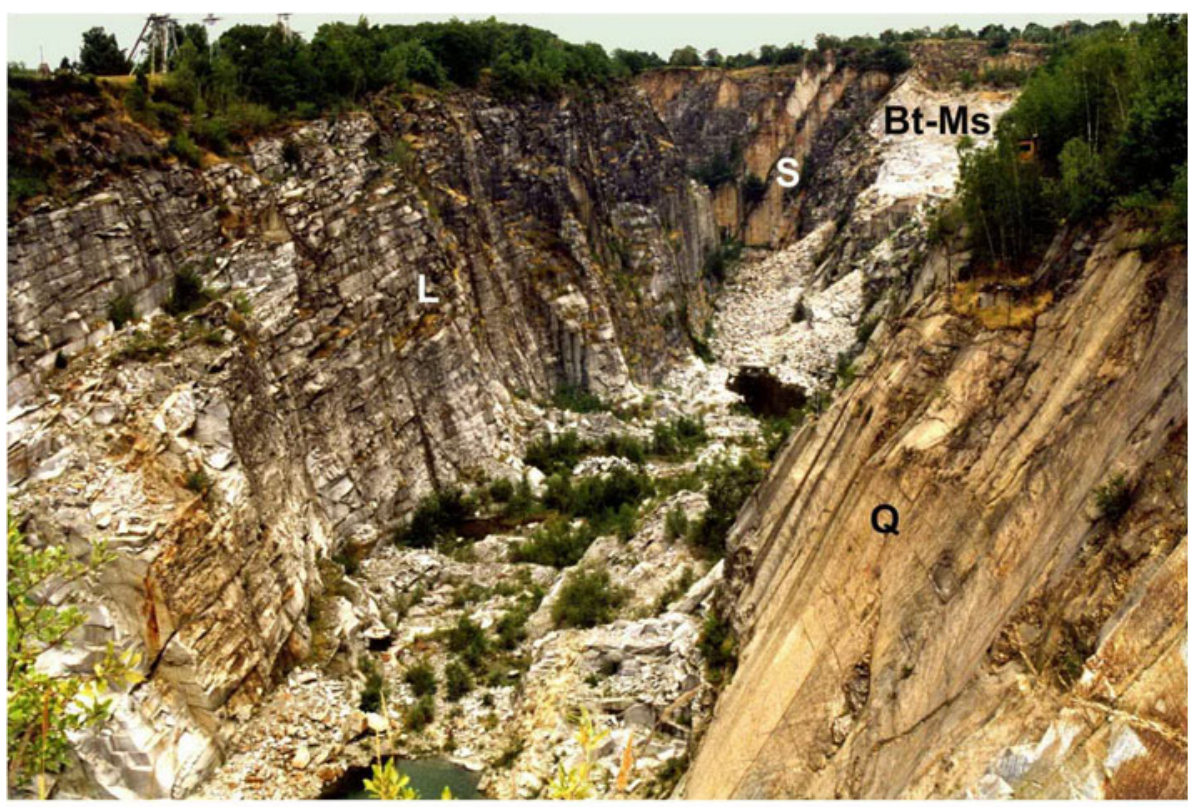

a

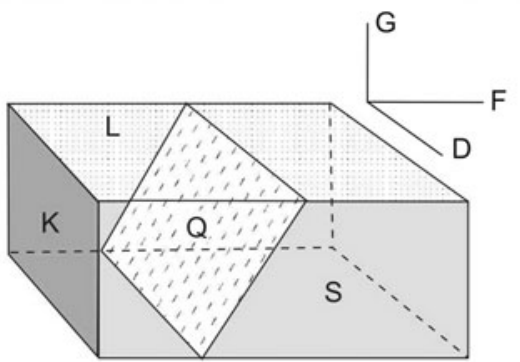

$\mathrm{S}$
$\mathrm{L}$

K

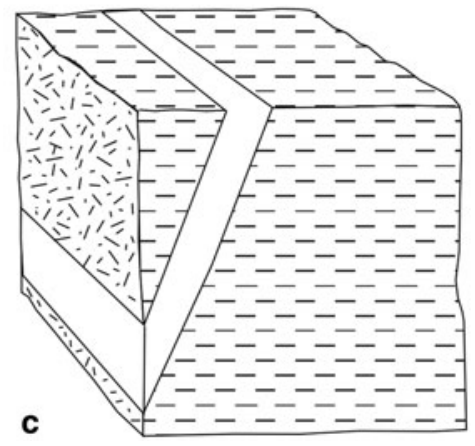

Strzelin granite and, referring to new geochronological data (Oberc-Dziedzic et al. 2013), we document three successive magmatic stages in this composite intrusion and draw inferences on the tectonic framework that prevailed during and after emplacement.

\section{Regional context and Cloos' granite tectonics studies}

The Sudetes situated in the northeasternmost part of the Central European Variscides are composed of fragments two crustal blocks: (a) the Bohemian Massif to which belong the West and Central Sudetes and (b) Brunovistulicum comprising the East Sudetes (Fig. 1b, c). The West Sudetes are considered a part the Saxothuringian Zone; the Central Sudetes are parts of Teplá-Barrandian and Moldanubian Zones (Fig. 1b) (Mazur et al. 2006; Franke 2012), all interpreted by some authors as terranes (Matte et al. 1990) of the Armorican Terrane Assemblage (Franke 2000). Brunovistulicum (Bruno-Vistulicum after Dudek 1980 ) is interpreted as an individual microcontinent (Pharaoh 1999; Schulmann and Gayer 2000) of the Avalonian affinity (Finger et al. 2000; Friedl et al. 2000). The boundary between the Moldanubian Zone and Brunovistulicum was recognized by Suess $(1912,1926)$ as the Moldanubian Overthrust.

The Sudetes host Variscan granitoid intrusions of various size and ages widely scattered between 350 and 290 Ma (Oberc-Dziedzic et al. 2010, 2012; Mazur et al. 2007; Fig. 1c). The granite bodies of the Sudetes were the object of the classical granite tectonics studies by Hans Cloos in the years 1919-1925, when he was a professor of geology and paleontology at the University of Wrocław (Breslau). These pioneering studies enabled the reconstruction of the emplacement dynamics of a pluton based on its internal structure (Cloos 1921, 1922a, b, 1925) and stand among the most significant achievements in geology at that time.

Hans Cloos started his work on granite tectonics (German: Granittektonik) in the Strzelin-Žulova Massif (das Granitmassiv von Strehlen und Friedeberg, Cloos 1922a), which was considered as one of the largest and continuous granitic bodies in the Sudetes area but at present is regarded as a group of small, isolated intrusions within gneisses 
Fig. 3 Map showing the location of quarries at Strzelin. Stereograms of the orientation of foliation (DF 1, DF 2) and mineral lineation (DL) in the metamorphic envelope of the granites (lower hemisphere, equal area projection; from Kowalczyk 2006)

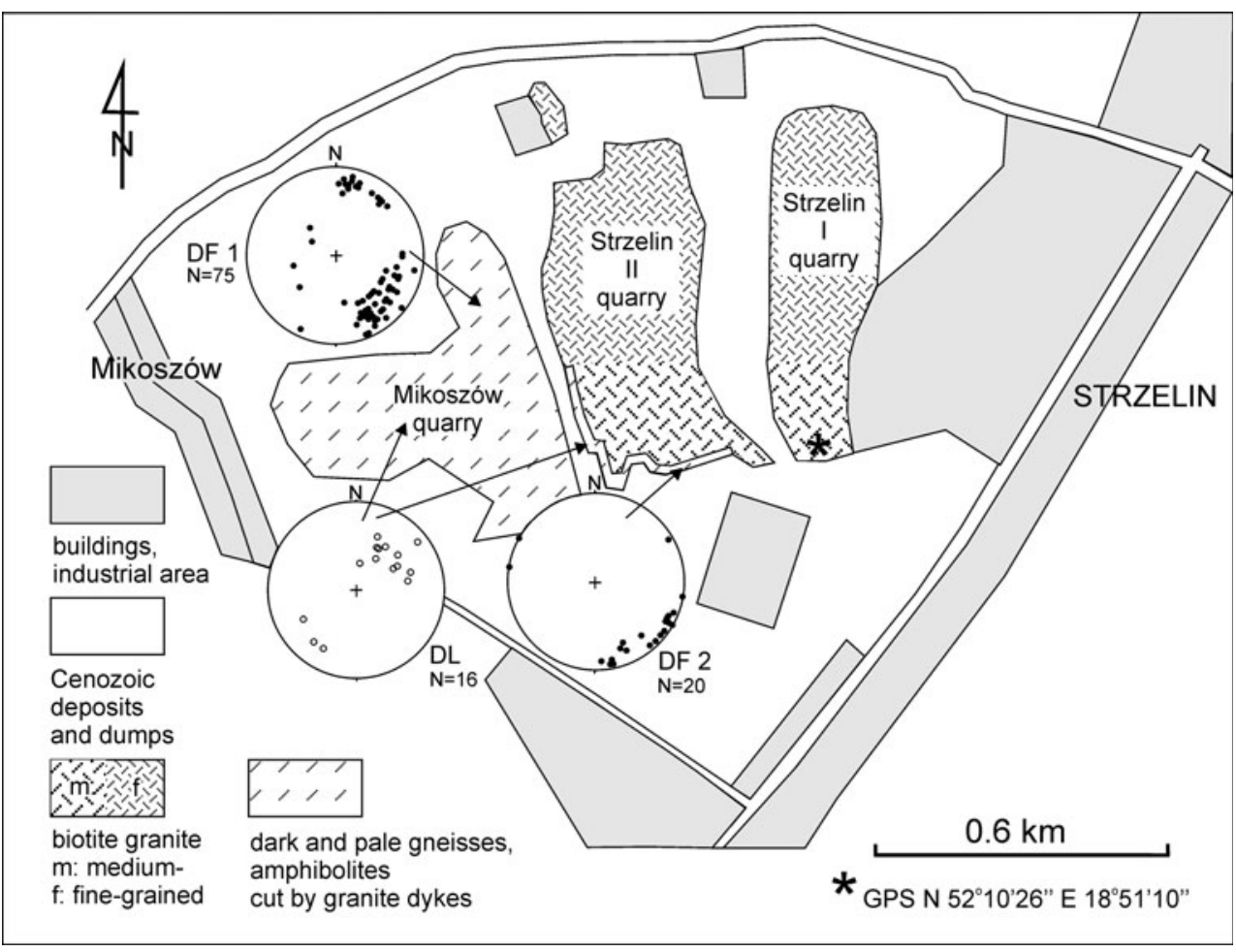

(Oberc-Dziedzic 1991). Cloos' tectonic studies concentrated on one of these granite bodies, namely the Strzelin intrusion located in the town of Strzelin, c. $35 \mathrm{~km}$ south of Wrocław (Figs. 1d, 2, 3).

In the Strzelin granite, Cloos recognized linear and planar flow structures of the solidifying magma. The linear structures are represented by parallel arrangement of elongated mineral grains and enclaves, both defining the lineation (Ger.: Streckung, Fig. 2b). The planar flow structures are marked by parallel arrangement of tabular crystals and magmatic layering (Schlieren). Cloos (1921) suggested that the lineation was caused by the "spreading" of magma, perpendicular to the tectonic compression and parallel to the direction of the lowest pressure during magma intrusion (Fig. 2b). The linear and planar structures were found parallel to the margins of the granite body: subhorizontal near the roof and steep near the side walls of the intrusion (Cloos 1922a).

The second group of the tectonic structures in granites is joints. Cloos (1921, 1922a, b) correlated them with the linear structures. Cross joints, or "Q joints" (Ger.: Querfläche), are always perpendicular to the linear flow structures (Fig. 2c) and are often filled with aplites or coated by chlorite, epidote or quartz. Cloos (1921) considered the Q joints as the earliest fractures in the intrusion. The steeply dipping longitudinal S joints (Ger.: Spalt Fläche, Längs/ Schiefer Fläche) are parallel to the linear flow structures and perpendicular to planar flow structures and to cross joints Q. The flat-lying L joints (Ger.: Lagerfläche) are parallel to the planar flow structures and perpendicular to the cross and longitudinal joints (Fig. 2b). Apart from the three basic joints Q, S and L, "artificial" fissures K (Ger.: Kopf Fläche) were also recognized in the Strzelin intrusion. They reveal during the exploitation of the granite in the quarries and are perpendicular to the linear flow structures as well as to the $\mathrm{S}$ and $\mathrm{L}$ joints. Furthermore, steeply dipping D joints (Ger.: Diagonal Klüfte), found in some plutons, are oblique to the linear flow structures.

The granite tectonics concept elaborated by Cloos (1921, 1922a) in the Strzelin granite was afterward applied by himself to the Karkonosze granite (Cloos 1925), the largest Sudetic pluton (KG in Fig. 1c) and to other granite plutons in Europe (e.g., to the Passau Forest plutons; Cloos 1927) and in North America. The original results of granite tectonics studies were published in 1922 in the monograph Tektonik und Magma, devoted mainly to the Sudetic granites (H. Cloos 1922b; Bederke 1922; Lopianowski 1922; E. Cloos 1922). Later on, the granite tectonics was developed and popularized among the English-speaking geologists by Balk (1937).

\section{A brief outline of the geology and geochronology of the Strzelin intrusion}

The Strzelin Massif (Fig. 1d) is composed of two structural units separated by the Strzelin Thrust considered the northern extension of the Moldanubian Thrust (Oberc-Dziedzic 
and Madej 2002; Oberc-Dziedzic et al. 2005; Fig. 1d). The lower structural unit - the footwall of the Strzelin Thrustbelongs to Brunovistulicum. This unit is composed of the Strzelin Complex containing orthogneisses of $c$. 600-570 Ma (Oberc-Dziedzic et al. 2003, 2005; Klimas 2008; Mazur et al. 2010). The upper structural unit-the hanging wall of the Strzelin Thrust-belongs to Moldanubicum (sensu Aleksandrowski and Mazur 2002). This unit is composed of the Stachów Complex containing orthogneisses of c. $500 \mathrm{Ma}$ (Oliver et al. 1993; Klimas 2008).

During the Variscan orogeny, the rocks of both units were metamorphosed and deformed, and the Moldanubian unit overthrust Brunovistulicum. Subsequently, the metamorphic rocks of the Strzelin Massif were intruded by Variscan granitoids, represented by quartz diorite, tonalite, granodiorite, biotite granite and biotite-muscovite granite. The granitoids form numerous and rather small, isolated bodies, mostly stocks and subhorizontal sheets, typically tens of meters thick (Oberc-Dziedzic 1991). The size and three-dimensional shape of the bodies were deduced from combining the outcrop patterns with structural observations, thermal aureoles and mutual relationships between granitoids and their metamorphic envelope in exposures and in a number of boreholes.

The new U-Pb SHRIMP ages (Oberc-Dziedzic et al. 2010, 2012 and 2013) show that granitoid plutonism in the Strzelin Massif occurred in three main stages: (1) tonalitic I-c. $324 \mathrm{Ma}$, (2) granodioritic-c. $305 \mathrm{Ma}$ and (3) tonalitic II/granitic - c. $295 \mathrm{Ma}$. The quartz diorites that form separate magmatic bodies, unrelated with the tonalites, have not been dated.
The Strzelin intrusion proper is composed of three varieties of granite: (1) the older, medium-grained biotite granite (303 $\pm 2 \mathrm{Ma})$; (2) the younger, fine-grained biotite granite, ( $283 \pm 8 \mathrm{Ma}$; both dated by the U-Pb SHRIMP method (Oberc-Dziedzic et al. 2013) and (3) the youngest, leucocratic, fine-grained biotite-muscovite granite (yet undated). The medium-grained biotite granite corresponds to the second granodioritic stage, whereas the remaining two correlate with the third tonalitic II/granitic stage of the Strzelin Massif. All types of granitoids are cut by thin aplite dykes.

\section{Field relationships, structural observations and petrography}

The Strzelin intrusion is well exposed in two large, active quarries (Fig. 3), Strzelin I (Fig. 2a) in the eastern and Strzelin II in the western part of the intrusion. The quarries cover nearly the whole outcrop (only $\sim 1 \mathrm{~km}^{2}$ ) of the intrusion. Most observations presented in this study come from these two quarries and, additionally, from 24 boreholes, 100-120 m deep, drilled for granite prospection. West of the Strzelin II quarry, apophyses of the main granite body within the metamorphic envelope crop out from beneath the Cenozoic cover in the Mikoszów quarry (Fig. 3) and in several small abandoned pits.

The Strzelin composite intrusion is a stock-type body with a thick, flat apophysis and numerous branching off dykes (Fig. 4; Oberc-Dziedzic 1991, 1999). The field relationships and structural features described hereafter
Fig. 4 Geological cross sections through the Strzelin intrusion, after Balawejder et al. (1988; above) and Borek (1987; below)

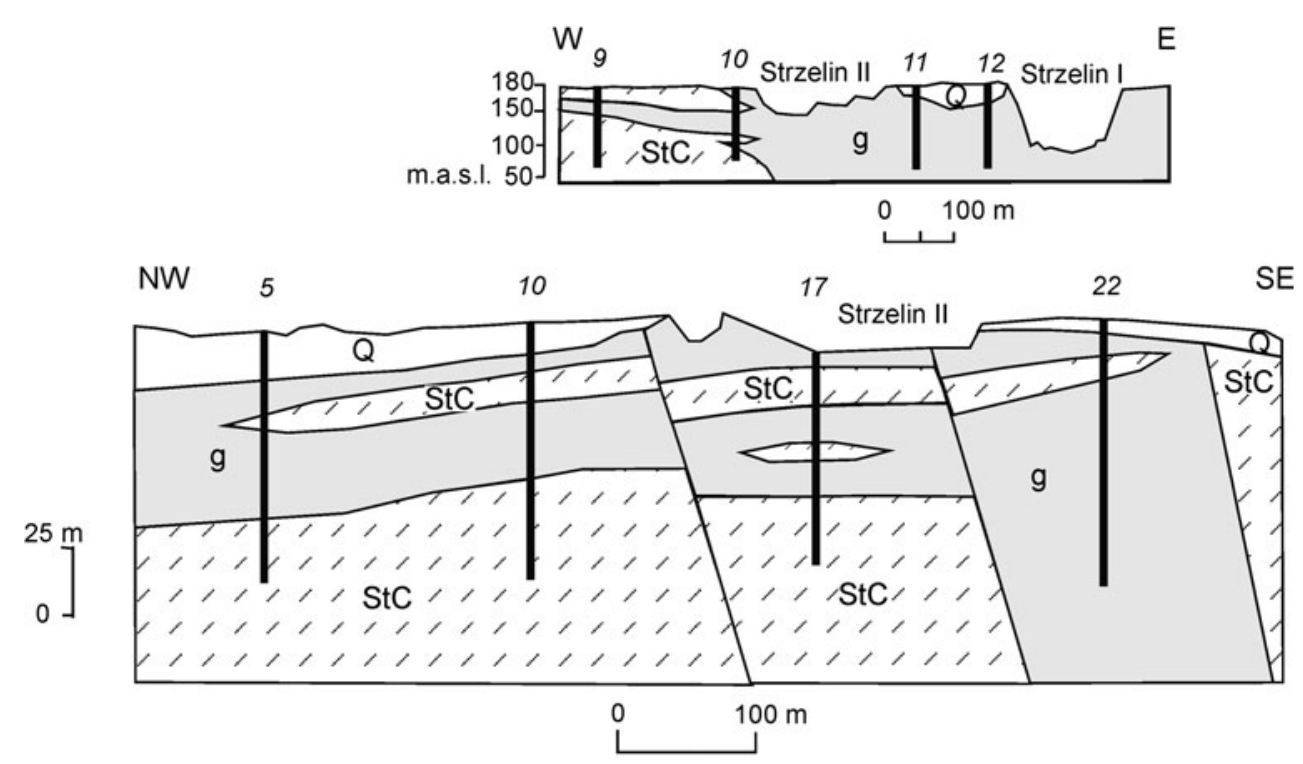

g Complex gneisses granite

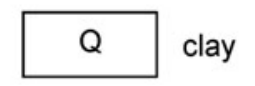

17 borehole number 
provide important constraints for the assessment of the physical conditions and structural framework of the granite emplacement.

Locally preserved roof rocks suggest that only the upper part of the Strzelin intrusion is exposed in the Strzelin I and Strzelin II quarries. The contacts of the granites with the metamorphic envelope composed of mica schists, amphibolites, ortho- (age of protolith $\sim 500 \mathrm{Ma}$, Klimas 2008) and paragneisses of the Stachów Complex are sharp and discordant. The foliation of the metamorphic rocks, generally dipping to the $\mathrm{NW}$ and $\mathrm{SW}$ at moderate angles (Fig. 3, DF 1), becomes steeper, nearly vertical (Fig. 3, DF 2) and, locally, bent adjacent to the contact with the granites (Oberc-Dziedzic 2007). Mineral lineation plunges to NE and SW at moderate angles (Fig. 3, DL). Faint contact metamorphic effects are limited to static mineral recrystallization, resulting in an isotropic fabric, and also evidenced by pinite pseudomorphs after cordierite.

The southern part of the Strzelin intrusion (Fig. 5) is formed by the pale-gray medium-grained biotite granite composed of 27.5-34.5\% quartz, 24.1-34.0\% microcline, 20.6-40.1\% plagioclase and 3.7-6.6 \% biotite (Morawski and Kościówko 1975). The average grain size is $2-5 \mathrm{~mm}$ but, generally, microcline grains are larger than plagioclase. The rock shows a faint WSW-ENE oriented, subhorizontal lineation defined by parallel alignment of plagioclase and quartz aggregates (Cloos 1922a; Oberc 1966; Bereś 1969).
The medium-grained granite forms a steeply dipping sheet, about $200 \mathrm{~m}$ thick. The southern contact of this granite with the country rocks is not exposed, but its proximity is indicated by numerous xenoliths composed of dark and pale gneisses of the Stachów Complex. These xenoliths are often surrounded by leucogranite. Tonalite xenoliths are scarce; dark, double microgranular enclaves (Didier 1973; Lorenc 1984) are only exceptionally found. A special kind of xenoliths is formed of very fine-grained granite, composed of plagioclase and microcline phenocrysts $(\sim 1.5 \mathrm{~mm}$ large) surrounded by a matrix of plagioclase, microcline, quartz and biotite $(\sim 0.5 \mathrm{~mm}$ grain size). The xenoliths of very fine-grained granite are interpreted as fragments of marginal granite facies incorporated into the medium-grained biotite granite.

Near the southern contact of the granite with the country rocks, a tens of meter wide zone of the medium-grained biotite granite contains centimeter- to decimeter-scale parallel, fine-grained bands (grains of $0.5-2.0 \mathrm{~mm}$ in size) alternating with medium-grained bands in which plagioclase is up to $3.0 \mathrm{~mm}$ and microcline up to $5.0 \mathrm{~mm}$ (Fig. 5). Both types of bands show a faint ENE-WSW trending, subhorizontal lineation (Cloos 1921; Oberc 1966; Bereś 1969) defined by the roughly parallel distribution of larger feldspar grains in the medium-grained bands, and of biotite plates in the fine-grained bands. The bands, that define a generally $\mathrm{E}-\mathrm{W}$ oriented steep magmatic foliation (compositional banding), have been deformed into open
Fig. 5 Schematic model of the Strzelin intrusion

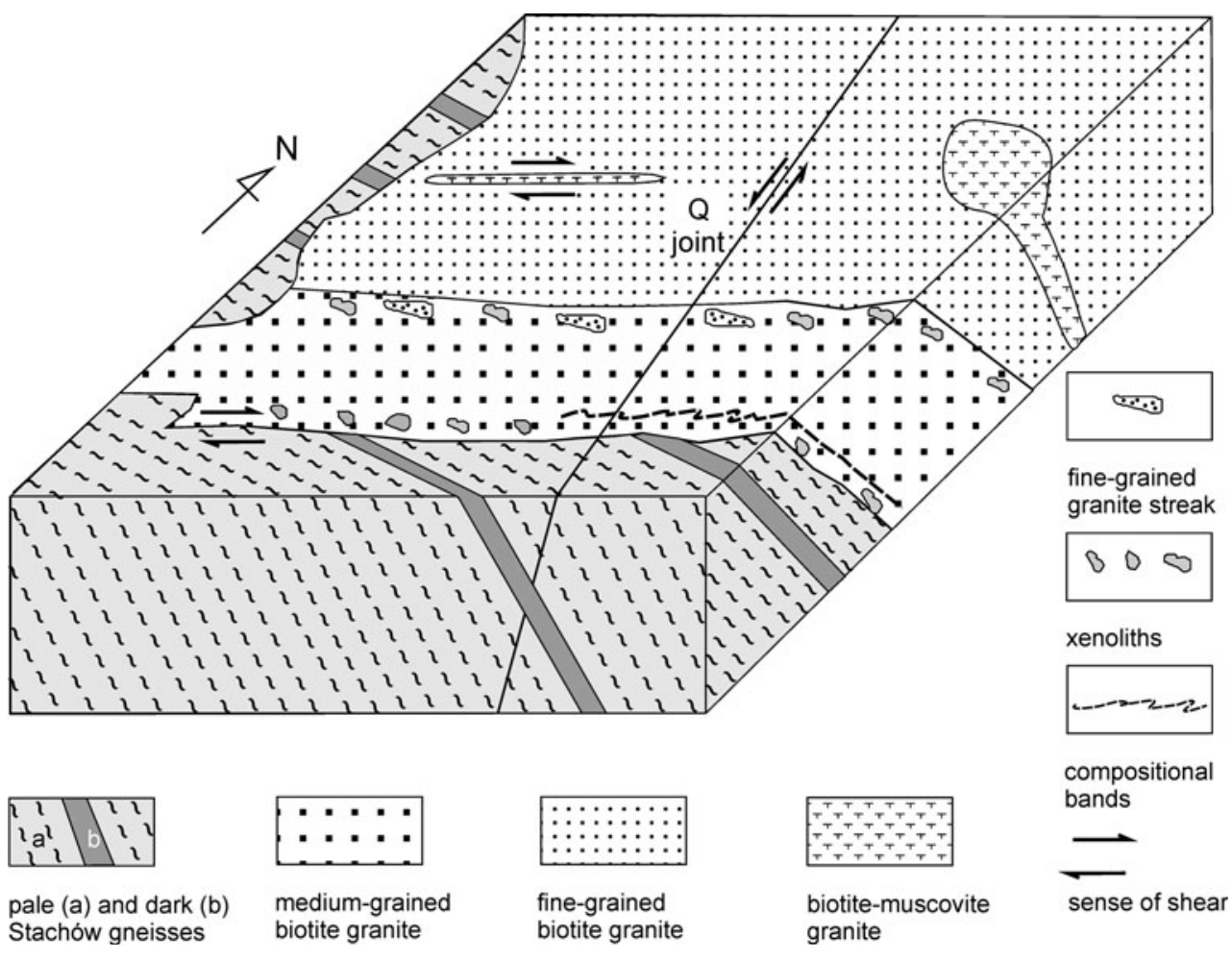


and tight folds (Fig. 6a). Xenoliths enclosed in the banded zone have been wrapped by several compositional layers of the granite. The layers close to the xenoliths follow their shapes, whereas further away they display a straight, undisturbed attitude (Fig. 6b). The minerals are arranged obliquely to the bands margins. In contact with the granite, the foliation of gneiss xenoliths is locally bent (Fig. 6c). Xenoliths and schlieren surrounding them are often cut by fractures. Along some rare fractures, a 2- to 3-cm offset of schlieren has been observed. These fractures are healed by granite in the segment cutting the xenolith (Fig. 6d). Mineral grains localized along the fractures do not show features of brittle deformation. In contrast, no displacement of xenoliths and surrounding schlieren has been observed along the fractures filled with quartz and aplite (Fig. 6b).

The northern part of the Strzelin intrusion is composed of the fine-grained biotite granite (Fig. 5), a gray rock, with a characteristic bluish tint. The modal composition of the fine-grained biotite granite is $28.7-30.9 \%$ quartz, 24.1-33.3\% microcline, $29.8-38.7 \%$ plagioclase and 4.6-8.9 \% biotite (Morawski and Kościówko 1975). The size of euhedral plagioclase grains is $0.5-1.5 \mathrm{~mm}$. Average size of other minerals is below $1 \mathrm{~mm}$. The fine-grained granite shows an ENE-WSW oriented, subhorizontal mineral lineation defined by parallel alignment of plagioclase grains. Overall, the granite seems to be homogenous but, in fact, particular parts of the granite body show subtle but very well visible differences in color, texture and proportions of the main minerals.

The poorly defined boundary between the mediumgrained and the fine-grained biotite granites generally strikes E-W and dips steeply to the north (Bereś 1969; Morawski and Kościówko 1975). Near the contact of the two granites, steep streaks and lenses of the fine-grained biotite granite, trending E-W to ENE-WSW, appear within the medium-grained one (Fig. 7a).

Close to the boundary between the two granites, the fine-grained granite contains relatively abundant xenoliths of country rocks and schlieren which originated by disaggregation of xenoliths (Fig. 7b). However, several tens of meters away from the contact, xenoliths vanish and the granite becomes monotonous or contains only sparse dark enclaves, $1-3 \mathrm{~cm}$ in size, or rhythmic layering (Barrière 1981; Fig. 7c).

Both the medium- and fine-grained biotite granites are cut by steep, several meters to tens of centimeters sized,
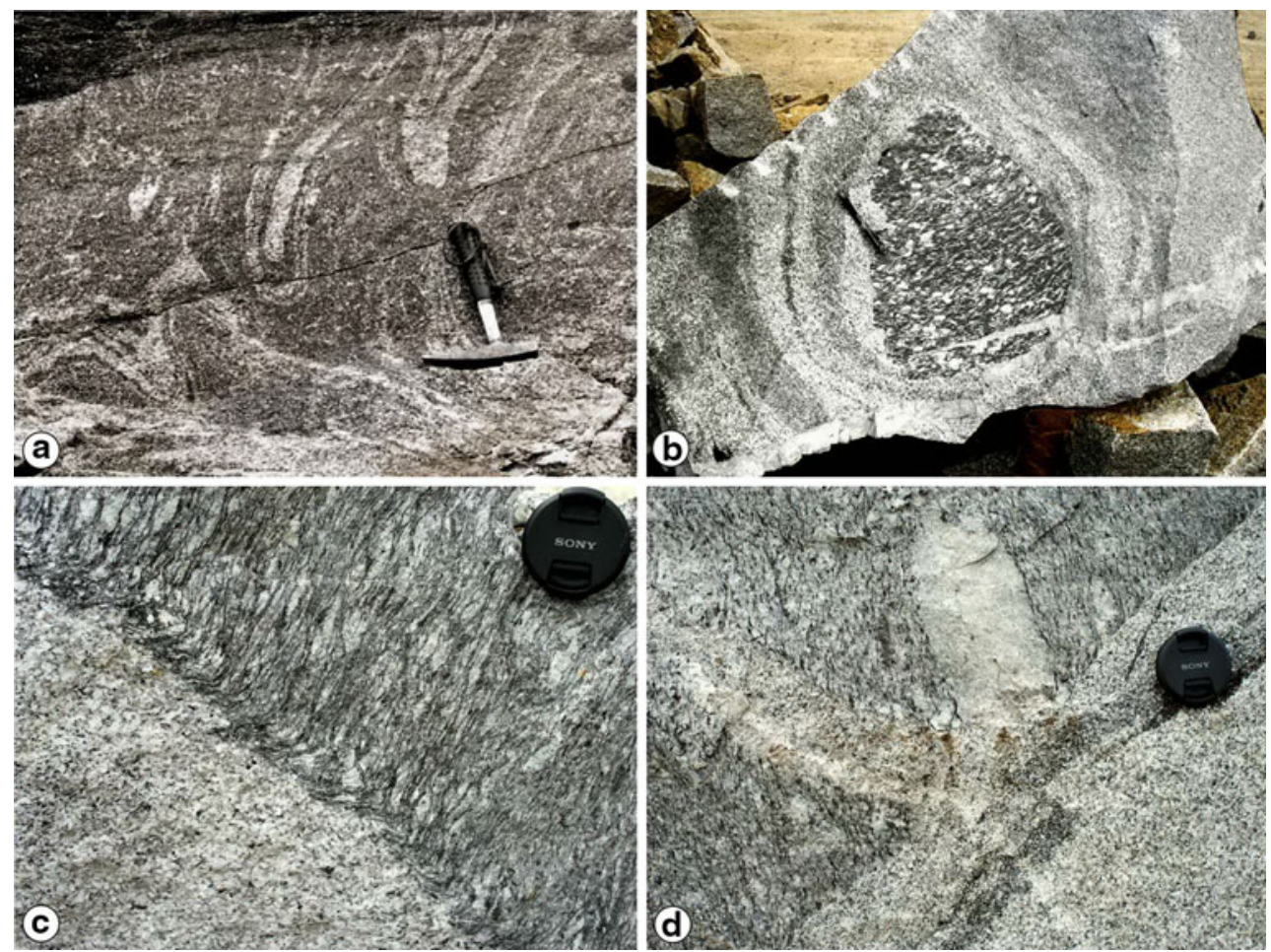

Fig. 6 Internal structures of the Strzelin intrusion. a Parallel bands in the marginal part of the medium-grained biotite granite deformed into tight folds; the length of hammer is $33 \mathrm{~cm}$. b Xenolith of gneiss wrapped by several compositional bands; the bands close to xenolith follow its shape, whereas more external ones are more planar; the mineral lineation marked by pen $(14.5 \mathrm{~cm}$ in length) is oblique to the margin of bands. c Xenolith of the pale Stachów gneiss showing

bending of foliation at the contact with granite. d Xenolith of the Stachów gneiss surrounded by schlieren offset along the fracture; no submagmatic deformation of minerals is observed close to fracture; part of the fault cutting the xenolith is healed by granite; both granite filling and schlieren are overprinted by a younger aplite dyke. Diameter of lens cover in $\mathrm{c}$ and $\mathrm{d}$ is $48 \mathrm{~mm}$ 

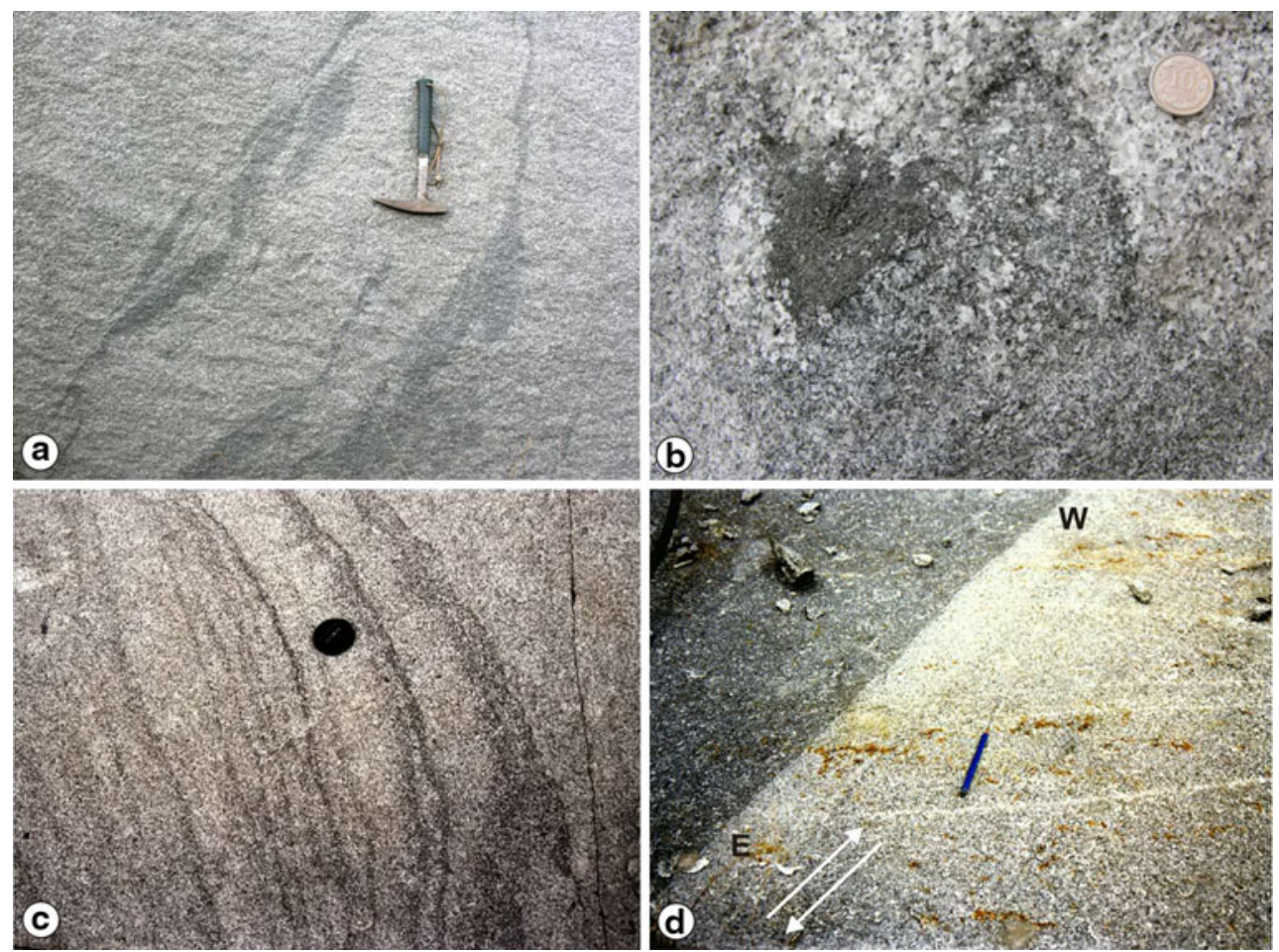

Fig. 7 Internal structures of the Strzelin intrusion. a Streaks and lenses of the fine-grained granite within the medium-grained granite; the length of hammer is $33 \mathrm{~cm}$. b Schlieren originated by disaggregation of a xenolith; diameter of coin is $15 \mathrm{~mm}$. c Rhythmic layering in the fine-grained biotite granite; diameter of lens cover is $48 \mathrm{~mm}$.

E-W to ESE-WNW striking dykes of the leucocratic finegrained, biotite-muscovite granite (Figs. 5, 7d). This granite is composed of $33.4-34.9 \%$ quartz, 30.6-31.3\% microcline, $28.4-29.7 \%$ plagioclase, $1.8-2.6 \%$ biotite and 2.5-2.8\% muscovite (Morawski and Kościówko 1975). It also contains euhedral pinite pseudomorphs after cordierite, and rare garnet. In the NE part of the Strzelin I quarry, the biotite-muscovite granite forms a sort of neck, several meters in diameter, surrounded by the fine-grained biotite granite (Fig. 5). The contacts between the biotite granites and the biotite-muscovite granite are usually sharp although, locally, gradual transitions can be observed.

All types of the granites are cut by rare, thin aplite dykes. Aplite is mesoscopically similar to the fine-grained biotite-muscovite granite. However, the grain size is below $0.5 \mathrm{~mm}$, and all minerals are anhedral in habit. The mineral composition of the aplite is similar to that of the biotitemuscovite granite, but pinite pseudomorphs are absent.

The aplite dykes mainly follow the Q joints (Cloos $1921,1922 \mathrm{a}, \mathrm{b})$, striking NWN to $\mathrm{N}$ and dipping $55-70^{\circ}$ to WSW or to W (Figs. 2, 5). The second system of longitudinal joints $\mathrm{S}$ is broadly vertical and ENE-WSW oriented, whereas the third joints system $\mathrm{L}$ is roughly horizontal (Fig. 2).

d Sharp contact $\left(108^{\circ} / 88^{\circ} \mathrm{N}\right)$ between the fine-grained biotite granite and the dyke of the biotite-muscovite granite showing foliation oblique to the walls of the dyke $\left(92^{\circ} / 88^{\circ} \mathrm{S}\right.$, marked by the pencil, $16 \mathrm{~cm}$ in length) and lineation $\left(20^{\circ} / 98^{\circ}\right.$, not marked); arrows show the sense of shear

\section{Deformation structures in the Strzelin granites}

\section{Synmagmatic deformation structures}

The spatial relationships between the Strzelin granites, such as injections of fine-grained biotite granite into marginal zone of the medium-grained biotite granite with numerous xenoliths of country rocks, and that both biotite granites are crosscut by dykes of biotite-muscovite granite, suggest that the medium-grained biotite granite intruded as the first, the fine-grained biotite granite as the second, and the biotite-muscovite granite as the third. This intrusive sequence is supported by the new SHRIMP age data: $303 \pm 2 \mathrm{Ma}$ for the medium-grained biotite granite, and $283 \pm 8 \mathrm{Ma}$ for the fine-grained biotite granite (ObercDziedzic et al. 2013).

In the oldest, medium-grained biotite granite, synmagmatic deformation resulted in a magmatic lineation and foliation, the latter expressed as intensively folded compositional banding (Fig. 6a). More homogenous parts of medium-grained biotite granite do not show any microscopic evidence of magmatic flow. However, there are indications of high temperature solid-state deformation, such as occasional, blocky (checkerboard, Pawley and 


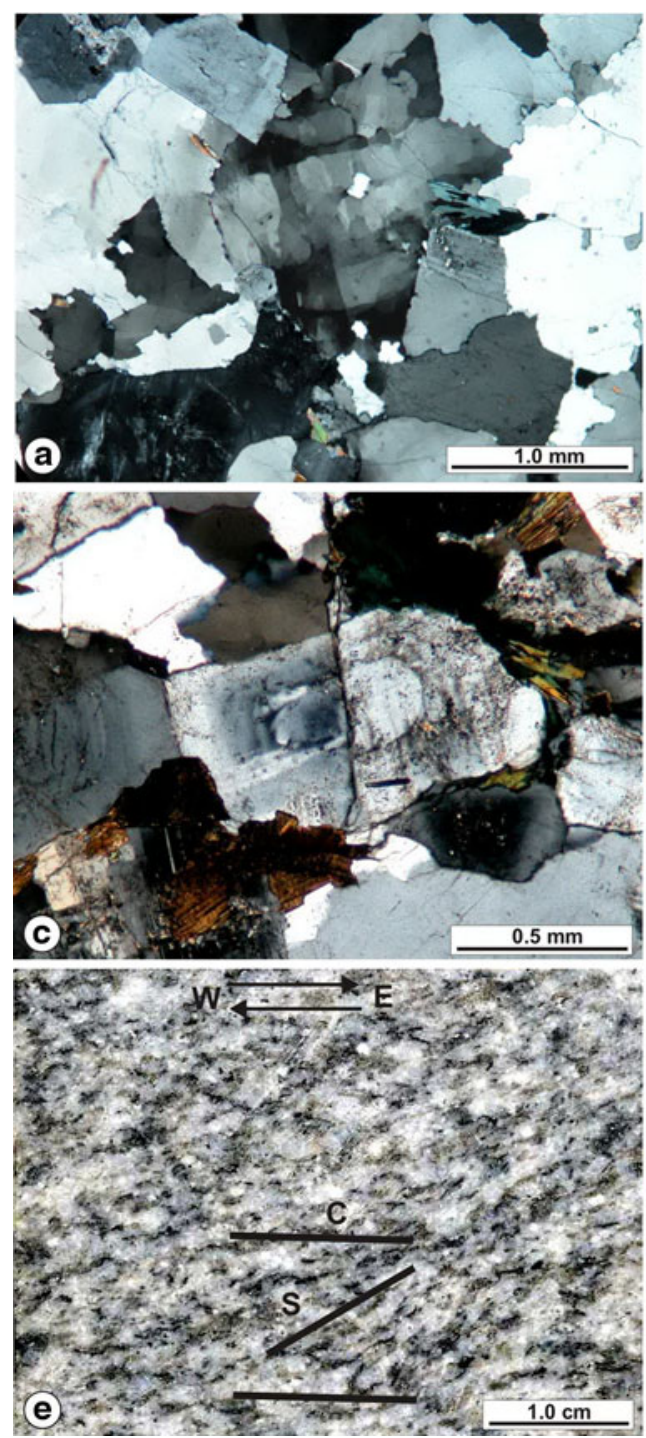

Fig. 8 Microscopic evidence of deformation in granites of the Strzelin intrusion. a High temperature deformation-blocky (checkerboard) subgrain texture of quartz grains in the medium-grained biotite granite. b Lobate grain boundaries pointing to grain boundary migration recrystallization in the medium-grained biotite granite. c Broken plagioclase grain in a fine-grained band of the mediumgrained biotite granite. $\mathbf{d}$ Microscopic evidence of magmatic flow in

Collins 2002) subgrain texture of quartz grains (Fig. 8a), suggesting $\mathrm{T}>650{ }^{\circ} \mathrm{C}$ (Kruhl 1996) and, also, lobate grain boundaries (Fig. 8b), indicative of recrystallization at 500-700 ${ }^{\circ} \mathrm{C}$ (Passschier and Trouw 2005).

More conspicuous signs of magmatic flow were detected in banded parts of the medium-grained granite. Finegrained bands show a faint parallel arrangement of biotite, enhanced by plagioclase and quartz crystal faces. Mediumgrained bands display a roughly parallel distribution of euhedral grains of microcline and plagioclase, which is considered as an indicator of magmatic flow (Paterson et al. 1989). Apart from structures related to magma

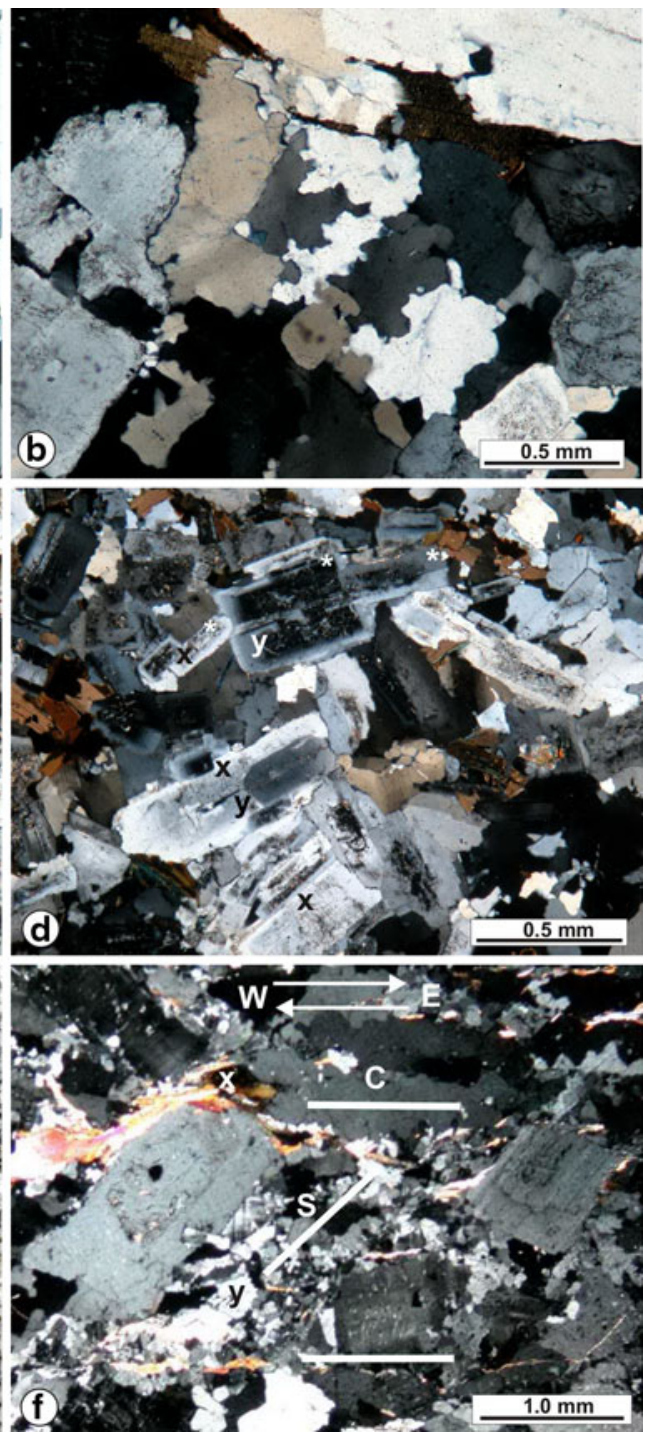

the fine-grained biotite granite: parallel and "train-like" arrangement of plagioclase (middle-upper part of the photograph *), tiling ( $\mathrm{x}$ ) and synneusis (y). e, f Mesoscopic (e) and microscopic (f) S-C structures pointing to submagmatic deformation in the fine-grained biotitemuscovite granite; $x$ biotite and muscovite cap, y dilatational site filled with fine grains of quartz, plagioclase and microcline; cross section parallel to magmatic lineation; arrows show the sense of shear

crystallization, the banded parts of the medium-grained granite show microscopic evidence of a later deformation, including broken plagioclase grains in fine-grained bands (Fig. 8c; Bouchez et al. 1992), blocky (checkerboard) subgrains and lobate (sutured) grain boundaries in quartz, bulging of quartz grains, pointing to strain-induced grain boundary migration, and undulose extinction. All these seldom detected features reflect deformation at decreasing temperature, between ca. 700 and $400{ }^{\circ} \mathrm{C}$ (Passschier and Trouw 2005), and resulting in folding of the granite bands.

In the younger fine-grained biotite granite, an ENEWSW oriented subhorizontal magmatic lineation is 
relatively well developed. This granite shows microscopic synmagmatic deformation structures, such as tiling of plagioclase grains (Blumenfeld and Bouchez 1988; Paterson et al. 1998), and synneusis and "train-like" arrangement of plagioclase (Fig. 8d), usually regarded as evidence of magmatic flow in the presence of $45-50 \%$ of liquid (Blumenfeld and Bouchez 1988; Paterson et al. 1998). However, this granite does not reveal any evidence of mineral deformation.

The youngest fine-grained biotite-muscovite granite, that forms steep E-W, ESE-WNW striking dykes, usually shows a foliation and lineation which are oblique to the walls of the dykes (Fig. 7d). At the mesoscopic (Fig. 8e) and microscopic scale (Fig. 8f), the S-C structures are discernible. The $\mathrm{C}$-planes are defined by parallel alignment of tiny biotite and muscovite plates and are parallel to the walls of a dyke. The S-planes are expressed by an alignment of euhedral zoned plagioclase and are oblique to the walls of dykes. Some plagioclase grains show sigmoidal shape and asymmetric strain caps of biotite and muscovite. Dilational sites around plagioclase grains are filled with fine grains of quartz, plagioclase and microcline not showing any signs of deformation (Fig. 8f). These minerals probably crystallized from the residual melt. Paterson et al. (1998) estimated that the S-C structures in solidifying magmas may form in the presence of $20-0 \%$ of melt.

The meso- and microscale S-C structures in the biotitemuscovite granite point to a dextral sense of shear. The same sense of shear can be deduced from the oblique orientation of magmatic foliation and lineation to the walls of dykes (Fig. 7d). Such obliquity, together with S-C microstructures, may indicate that the biotite-muscovite granite was injected into active faults (Blumenfeld and Bouchez 1988).

In contrast to the observations from the dykes, magmatic foliation and lineation were not detected in the biotitemuscovite granite in the neck-like body (Fig. 5).

\section{Brittle deformation structures}

As mentioned above, all types of the Strzelin granites are cut by the three systems of joints (Cloos 1921, 1922a):

- $\mathrm{Q}$ (cross joints) $=$ the steeply dipping joints that strike NNW to N, and dip 55-70 WSW to W (Figs. 2, 5 and 10a), that is, perpendicularly to the ENE-WSW trending lineation;

- $\mathrm{S}$ (longitudinal joints) = the system of ENE-WSW oriented vertical joints parallel to the lineation (Fig. 2);

- L, the third system of subhorizontal joints (Fig. 2).

It is worth noticing that, according to the Cloos' concept of granite tectonics, the longer axis of the Strzelin intrusion should be parallel to the lineation, that is, approximately
ENE-WSW oriented. Actually, the E-W and N-S intrusion dimensions, at the present erosion level, are nearly equal (Figs. 1d, 3).

After the emplacement of the youngest, fine-grained biotite-muscovite granite, the Strzelin intrusion was in extensional regime which controlled the formation of the $\mathrm{Q}$ joints. At the beginning of the extensional tectonic event, the $\mathrm{Q}$ joints, along which dilatational opening had occurred, were locally filled with aplite. In places, aplite dykes pass into feather dykes (Passchier and Trouw 2005; Fig. 9a) or into en échelon dyke arrays (Fig. 9b), both interpreted as extensional structures (Smith 1996). However, the sigmoidal shape of these structures suggests contemporaneous sinistral shear (Fig. 9b).

The $\mathrm{Q}$ joints system comprises fractures of different size, but of similar orientation. The most spectacular forms of the Q joints are even, vast surfaces, well exposed in the big quarries, of hundreds square meters in size, showing plumose (feather-like) structures, typical of extensional fractures (Figs. 2, 9c). The fracture ornamentation is marked by chlorite, clinozoisite and albite. Two systems of striations are developed on the $\mathrm{Q}$ fractures. The older striations are superposed on ornamentation and marked by chlorite (Fig. 9c). Their orientation varies from oblique (plunge to SW) to parallel to the dip of the $\mathrm{Q}$ planes (Fig. 10b; Oberc 1966). The younger rare striations, found on $\mathrm{Q}$ surfaces covered with calcite, plunge to $\mathrm{NW}$ at moderate angles. Both striations document oblique-slip shear movements along the Q surfaces. The superposition of striations showing different orientation suggests a recurrence of movements along the $\mathrm{Q}$ surfaces in more than one direction. All these features allow interpreting the vast $\mathrm{Q}$ surfaces as faults. The amplitude of displacement along them is unknown.

The Q surfaces of several square meters in size can be interpreted as minor shear fractures (Price and Cosgrove 1994). The displacement of biotite-muscovite granite dyke measured on horizontal surface along one of such fractures is within a range of several centimeters, with a sinistral sense.

More abundant than the vast surfaces described above are small Q fractures, spaced $20 \mathrm{~cm}$ to several meters and traced on short distances as numerous subparallel planar segments. On the horizontal surfaces, they are found as extensional arrays (Rothery 1988), locally with evidence of sinistral offset (Fig. 9d). The sinistral sense of shear is also indicated by asymmetric dilational jogs (Tikoff and Teyssier 1992) filled with chlorite in through-going joint system (Fig. 9e).

On the vertical surfaces parallel to the dip of Q planes, the small $\mathrm{Q}$ fractures are marked as straight lines passing into en échelon arrays or, rarely, into horse-tail structures, both pointing to a normal sense of movement (Fig. 9f). 



Fig. 9 Post-magmatic deformation structures. a Feather dyke of aplite parallel to $\mathrm{Q}$ joint in the fine-grained biotite granite viewed on horizontal surface; en-échelon gashes point to sinistral sense of shear (white arrows) along the $\mathrm{Q}$ joint. b En-échelon arrangement of tension gashes filled with aplite indicates sinistral sense of shear (white arrows); diameter of lens cover is $48 \mathrm{~mm}$. c Surface of the Q fracture, showing plumose (feather-like) pattern marked by chlorite and albite. The striations are superposed on the ornamentation; the length of hammer is $33 \mathrm{~cm}$. d, e Details of development of the Q

The Q joints were penetrated by fluids during, or probably immediately after, their formation. The fluids reacted with the granite and deposited some minerals, such as clinozoisite and chlorite, within the joints. The bleached reaction zones are up to several centimeters wide (Fig. 9f). This process was described in details by Ciesielczuk and Janeczek (2004) and Ciesielczuk (2007). The striations were formed after filling the joints by chlorite and clinozoisite.

The ENE-WSW oriented vertical S joints form vast and even surfaces (Fig. 2) without mineralization and striations, which suggests that they are younger than the $\mathrm{Q}$ joints. The subhorizontal L joints (Fig. 2) are also younger fractures viewed on horizontal surface: d Subparallel, planar segments, marked as extensional array, diameter of coin is $15 \mathrm{~mm}$. e Dilational jogs filled with chlorite in through-going joint system; the sinistral sense of shear is shown by white arrows; diameter of lens cover is $48 \mathrm{~mm}$. f Fractures viewed on vertical surface parallel to the dip of Q joint are marked as straight lines or en-échelon array pointing to the normal sense of shear; granite along the fracture is strongly altered; diameter of coin is $20 \mathrm{~mm}$

than the $Q$ joints and do not show any mineralization. They may reflect extension caused by final uplift.

\section{Discussion: tectonic control on the emplacement and solidification of the Strzelin granites}

The sharp and discordant contacts of the granites with the metamorphic country rocks and, in general, the lack of significant deformation in the granites, point to an overall post-tectonic character of the intrusion and indicate that the emplacement postdated the main phase of the Variscan regional metamorphism and deformation. The reorientation 
Fig. 10 Stereonets (lower hemisphere, equal area projection) showing orientation of: a Q, S, and L joints, b slickensides ( $\mathrm{n}$ - pole to $\mathrm{Q}$ joints; $\mathrm{Q}$ joints plane) in the Strzelin I and Strzelin II quarries; measurements after Ochnik (2003)
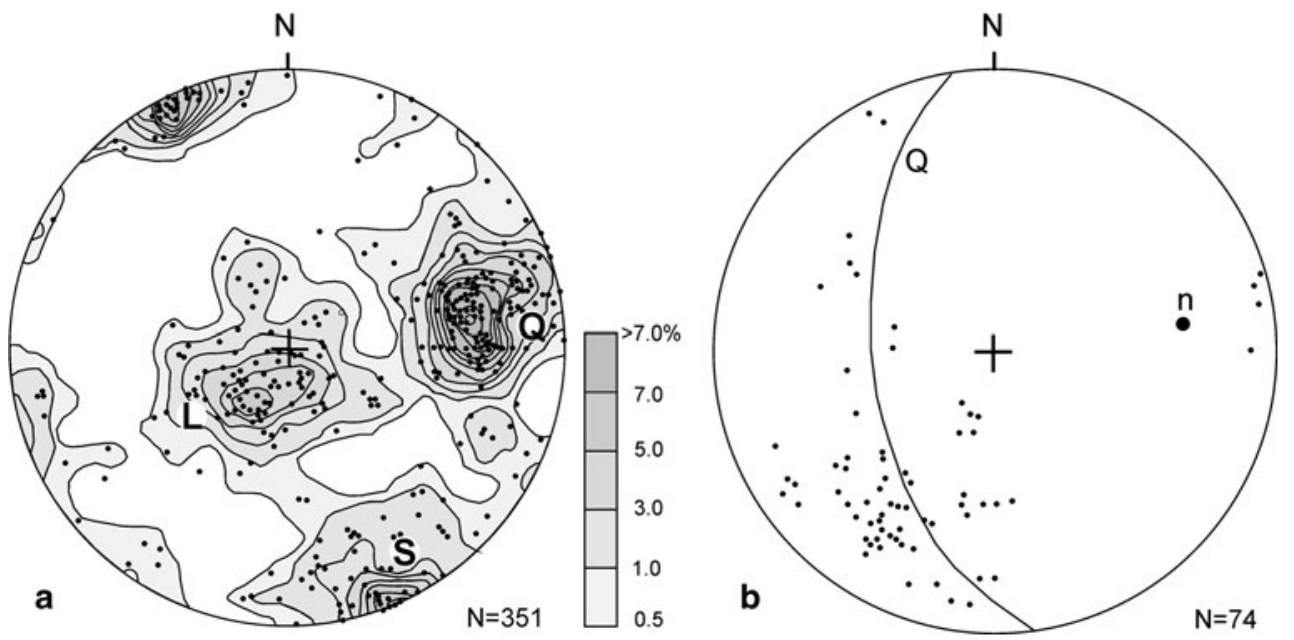

of the foliation in the country rocks adjacent to the contact with the medium-grained biotite granite (Oberc-Dziedzic 2007) suggests a forceful character of the intrusion, at least during the first magmatic episode. The weak contact metamorphic effects produced by the intrusion reflect the small size of the granite body and, also, the relatively high grade of regional metamorphism of the country rocks.

The presence of xenoliths in the contact zone between the medium- and fine-grained biotite granites indicates that the fine-grained granite could have been emplaced along the primary, northern contact of the medium-grained granite with the country rocks (Fig. 11). The contact between the medium- and the fine-grained biotite granites is rather gradational which indicates possible overlapping of solidification processes of these two portions of the intrusion. However, sharp margins and similar orientation of the fine-grained granite injections (Fig. 7a) in the medium-grained biotite granite suggest that the magma of the fine-grained granite intruded into the already consolidated, rather than unconsolidated, medium-grained granite. Taking this fact into account, and also bearing in mind considerable age difference between the medium and finegrained granites, the gradational contacts between the two granites could be explained as an effect of reworking of the older medium-grained granite by the younger magma of the fine-grained granite, but this supposition would need testing by further investigations.

The similar E-W to ESE-WNW orientation of all three granite varieties, together with the constant ENE-WSW orientation of shallowly plunging, faint magmatic lineation, suggest that the emplacement of all three varieties, in spite of their significant age differences (Oberc-Dziedzic et al. 2013), was tectonically controlled and took place within the same tectonic setting. Specifically, the granite emplacement was most likely controlled by an active strike-slip fault striking WNW-ESE (Fig. 11a). During the emplacement of the medium-grained biotite granite magma and shortly after
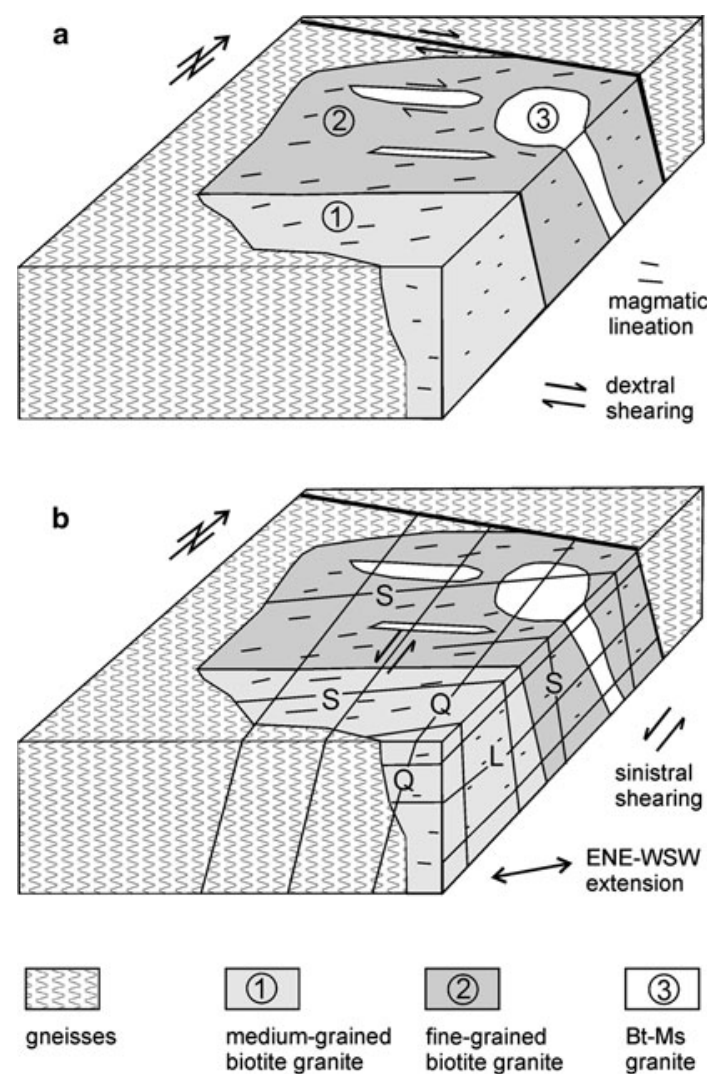

Fig. 11 Cartoon showing different structural regimes: a Dextral W-E shearing in a strike-slip fault setting during the magmatic emplacement, and $\mathbf{b}$ ENE-WSW extension during post-magmatic consolidation and joint system development in the composite Strzelin intrusion

its solidification, at temperature from $\sim 700$ to $\sim 400{ }^{\circ} \mathrm{C}$, the movements along this fault produced tight folds within the banded granite (Figs. 4 and 5a). The asymmetry of these folds points to a dextral sense of movement.

The dextral regime prevailing at the time of magma emplacement is also indicated by the relationship between the dyke margins and the foliation in the biotite-muscovite 
granite, and from the $\mathrm{S}-\mathrm{C}$ structures found in this rock (Fig. 8e, f). However, the deformation in this granite ceased before its crystallization was completed.

The fabric patterns near xenoliths provide some useful suggestions about magma/xenoliths relationships (Paterson and Miller 1998). The white granite haloes around some xenoliths can be interpreted as chilled margins. A temperature difference between the xenoliths and magma might have been large enough to force the crystallization of the banded rings around the xenoliths in the flowing magma (Fig. 6b). The magma flow is inferred from the fact that at some distance from the xenoliths, the bands become straight (Fig. 6b). Similar "straightening" of the granite bands away from the xenoliths was described from other intrusions (Paterson and Miller 1998; Pawley and Collins 2002). The alignment of minerals oblique to the margins of the bands resembles $\mathrm{S}-\mathrm{C}$ structures that could have been formed just before final granite consolidation. Some gneiss xenoliths are not surrounded by schlieren or bands. At the border with the granite, their foliation is often deflected (Fig. 6c) which suggests that the gneiss was softened by heating from the enclosing magma and its foliation was deformed during magma flow.

The materials that fill the fractures in the xenoliths allow correlating the fracturing with magma crystallization process (Fig. 6b, d). The fracturation started after the crystallization of schlieren that surround xenoliths, but still in the presence of granitic melt. This is supported by the offset schlieren, but without submagmatic deformation of minerals close to the fractures (Paterson et al. 1998; Gawęda and Szopa 2011), and by the fact that some fractures cutting the xenolith were healed by the granite magma. Even younger fractures, cutting through the xenoliths without displacement of the surrounding schlieren, have been filled with aplite and quartz (Fig. 6b, d).

The Strzelin intrusion shows many features typical of a sheeted granite pluton emplaced into an active fault or shear zone by injection of multiple magmatic sheets (Hutton 1992; Pitcher 1993). These features are strikeparallel, steeply inclined sheets of granite intruded into each other, relative homogeneity reflecting little petrographical differences between the granite sheets, the lack of chilled margins between the successive granites, and the presence of "ghost stratigraphy," that is, the strike-parallel zone of country rocks xenoliths between the mediumgrained and fine-grained biotite granites. A distinctive feature of the Strzelin intrusion, compared with the typical sheeted fault-related plutons, is its form. The sheeted plutons typically are elongated, usually parallel to the master fault, whereas the Strzelin intrusion has its N-S and E-W dimensions nearly equal (at the present-day erosion level). Taking into account the small size of the Strzelin intrusion, we may assume that the successive magma injections intruded only local dilation zones within fault system, and not a wider coherent space of this system. The time span between the two main magma pulses that produced the medium- and fine-grained biotite granites was about $20 \mathrm{Ma}$. It suggests that the fault which, assumingly, controlled the injections of magma, was episodically activated. Structural observations, especially those from the biotitemuscovite granite, indicate that it was a dextral WNWESE oriented strike-slip fault (Fig. 11a).

After the emplacement of the youngest fine-grained biotite-muscovite granite, the Strzelin intrusion was subjected to generally ENE-WSW to E-W oriented extension (Fig. 11b) which resulted in the formation of the Q fractures that display features typical of extension and hybrid fractures. The extensional fractures are filled with aplite or show plumose (feather-like) structures. The hybrid fractures combine features indicative for dilation and shearing such as feather aplite veins, tension gashes and dilational jogs all showing evidence of sinistral $\mathrm{N}-\mathrm{S}$ oriented displacements. The extensional $\mathrm{Q}$ fractures were subsequently reactivated by shearing as documented by striations superposed on plumose structures and by sinistral displacements of biotite-muscovite granite dykes.

The observed common features of the extensional and hybrid fractures, both accompanied by aplite and the same sinistral N-S oriented displacements along the hybrid fractures and reactivated extensional fractures, point to continuous transition from extension to shearing during the formation of the $\mathrm{Q}$ fractures.

The Strzelin intrusion served as an original and natural model in Hans Cloos' (1921, 1922a) concept of granite tectonics that was based on the apparent close relationship between the magmatic fabric and the joints. Our observations in the Strzelin intrusion suggest, however, that in spite of the observed geometrical links between the magmatic fabric and joints, there is no direct genetic and temporal correlation between them. In our opinion, the internal structures of the Strzelin intrusion, including the lineation, were formed earlier and in a different tectonic environment (WNW-ESE oriented dextral strike-slip zone) than the Q fractures that originated during ENE-WSW to $\mathrm{E}-\mathrm{W}$ extension and minor $\mathrm{N}-\mathrm{S}$ directed sinistral shearing (Fig. 11). It is possible that the geometrical attitude of joints was somewhat "guided" by earlier igneous fabric, via some kind of "inheritance" that was linked to the preexisting-from the igneous stage-anisotropy of the rocks. However, the igneous internal structures, such as the magmatic foliation and lineation, and the brittle structures, such as the joint system, were formed under different tectonic regimes. A similar idea assuming the lack of direct genetic correlation between the magmatic fabric and joints was proposed earlier by Žák et al. $(2006,2009)$ for the Karkonoše-Jizera Plutonic Complex (KG in Fig. 1c). 


\section{Conclusions}

1. The emplacement of the three successive granite magma pulses in the Strzelin intrusion was controlled by an active, long-lived tectonic structure, presumably a WNW-ESE oriented dextral strike-slip fault. Under this persisting structural framework, the internal structures of the intrusion, such as the faint foliation and lineation in the granites, and tight folds in the banded varieties, were formed.

2. After the emplacement of the third, youngest granite, that is, the fine-grained biotite-muscovite granite, the Strzelin intrusion was subjected to ENE-WSW to E-W extension, under which a shear fractures system was formed. The $\mathrm{Q}$ fractures show features typical of extension and hybrid fractures, and evidence of superposed $\mathrm{N}-\mathrm{S}$ oriented sinistral displacements; these fractures were penetrated by fluids which produced epidote and chlorite mineralization within the fractures.

3. We do not concur with Hans Cloos' (1922a) interpretation that assumed a close genetic link between the magmatic fabric and the joints. In our opinion, the internal structure of the Strzelin intrusion was formed during a long-lasting tectonic framework, under conditions that were markedly different during and after the emplacement. In spite of geometrical links between the magmatic fabric and the joints, there is no direct genetic and temporal correlation between them.

Acknowledgments The research was carried out under the Project N307 008 32/0314 of the Polish Ministry of Science and Education. Additional support came from internal grants 1017/S/ING and 2022/W/ING of the University of Wrocław. K. Ochnik is acknowledged for assistance during penetrations of the Strzelin I quarry abyss (and his singing of Gregorian chants there). J. Szczepański took some valuable photographs. Jiři Žak and an anonymous reviewer are thanked for their careful and constructive reviews.

Open Access This article is distributed under the terms of the Creative Commons Attribution License which permits any use, distribution, and reproduction in any medium, provided the original author(s) and the source are credited.

\section{References}

Aleksandrowski P, Mazur S (2002) Collage tectonics in the northeasternmost part of the Variscan Belt: the Sudetes, Bohemian Massif. In: Winchester JA, Pharaoh T, Verniers J (eds) Palaeozoic Amalgamation of Central Europe, Geol Soc London Spec Publ London 201:237-277

Balawejder J, Kryza G, Kuśnierz A (1988) Relationship between the Strzelin granites and their metamorphic envelope (in Polish). In: Budowa, rozwój i surowce skalne krystaliniku strzelińskiego (in Polish). Materiały do sesji naukowej 14.X.-15.X. 1988. Instytut Nauk Geologicznych Uniwersytetu Wrocławskiego. Przedsiębiorstwo Geologiczne we Wrocławiu. Wrocław, pp 81-85
Balk R (1937) Structural behaviour of igneous rocks. Geol Soc Am Mem 5

Barrierè M (1981) On curved laminae, gradded layers, convection currents and dynamic crystal sorting in the Ploumanac'h (Brittany) subalkaline granite. Contrib Mineral Petrol 77:214-224

Bederke E (1922) Die Intrusivmasse von Glatz-Reichenstein. Tektonik und Magma. Untersuchungen zur Geologie der Tiefen. Abh Preuss Geol L-A NF 89:39-70

Bereś B (1969) Petrography of granite of the environments of Strzelin (in Polish with English summary). Arch Miner 28:5-105

Blumenfeld P, Bouchez JL (1988) Shear criteria in granite and migmatite deformed in the magmatic and solid states. J Struct Geol 10:361-372

Borek Z (1987) Comprehensive geological documentation of granitoid resources in the "Strzelin Region of Exploitation of Stone Deposits" (in Polish). Archiwum Przedsiębiorstwa Geologicznego we Wrocławiu

Bouchez JJ, Delas C, Gleizes G, Nédélec A, Cuney M (1992) Submagmatic microfractures in granites. Geology 20:35-38

Ciesielczuk J (2007) Hydrothermal activity in the Strzelin granite, SW Poland. In: Kozłowski A, Wiszniewska J (eds) Granitoids in Poland AM Monograph 1, Warszawa, pp 231-242

Ciesielczuk J, Janeczek J (2004) Hydrothermal alteration of the Strzelin granite, SW Poland. N Jb Miner Abh 179:239-264

Cloos H (1920) Geologie der Scholen in schlesischen Tiefengesteinen. Neue Untersuchungen im Grenzgebite der Gebirgsbildung. Abh Preuss Geol L-A 81:1-123

Cloos H (1921) Der Mechanismus Tiefvulkanischer Vorgange. Sammlung Vieweg \& Sohn Braunschweig

Cloos E (1922) Tektonik des Granits von Gorkau (Kr. Nimptsch) in Schlesien. Tektonik und Magma. Untersuchungen zur Geologie der Tiefen. Abh Preuss Geol L-A NF 89:91-102

Cloos H (1922a) Die Gebirgsbau Schlesien und die Stellung seiner Bodenschätze. Verlag von Gebrüder Borntraeger, Berlin

Cloos H (1922b) Einleitung: Über Ausbau und Anwendung der granit-tektonischen Methode. Tektonik und Magma. Untersuchungen zur Geologie der Tiefen. Abh Preuss Geol L-A NF 89:2-18

Cloos H (1925) Einführung in die tektonische Behandlung magmatischer Erscheinungen (Granittektonik). I Spez Teil. Das Riesengebirge in Schlesien. Verlag Borntraeger, Belin

Cloos H (1927) Die Plutone des Passauer Waldes. Monogr z Geol u Pal Serie II H 3

Didier J (1973) Granites and their enclaves. The bearing of enclaves on the origin of granites. Elsevier, Amsterdam London

Dudek A (1980) The crystalline basement block of the outer Carpathians in Moravia-Bruno-Vistulicum. Rozpr Československé Akad véd, Ř Mat Přir véd 90:1-85

Finger F, Roberts MP, Haunschmid B, Schermaier A, Steyrer HP (1997) Variscan granitoid of central Europe: their topology, potential sources and tectonothermal relations. Miner Petrology 61:67-96

Finger F, Hanžl P, Pin C, Von Quadt A, Steyrer HP (2000) The Brunovistulian: Avalonian Precambrian sequence at the eastern end of the Central European Variscides? In: Franke W, Haak V, Oncken O, Tanner D (eds), Orogenic processes: quantification and modelling in the Variscan belt. Geol Soc London Spec Publ London 179:103-112

Franke W (2000) The mid-European segment of the Variscides: tectonostratigraphic units, terrane boundaries and plate tectonic evolution. In: Franke W, Haak V, Oncken O, Tanner D (eds), Orogenic Processes: Quantification and Modelling in the Variscan Belt. Geol Soc London Spec Publ London 179:35-61

Franke W (2012) Comment on Dörr and Zulauf: elevator tectonics and orogenic collapse of a Tibetan-style plateau in the European Variscides: the role of the Bohemian shear zone. Int J Earth Sci 
(Geol Rundsch) (2010) 99: 299-325. Int J Earth Sci (Geol Rundsch) 101:2027-2034

Friedl G, Finger F, McNaughton NJ, Fletcher JR (2000) Deducing the ancestry of terranes: SHRIMP evidence for South Americaderived Gondwana fragments in central Europe. Geology 28:1035-1038

Gawęda A, Szopa K (2011) The origin of magmatic layering in the High Tatra granite, Central Western Carpathians-implications for the formation of granitoid plutons. Earth Env Sci Trans Roy Soc Edinb 102:129-144

Hutton DWH (1992) Granite sheeted complexes: evidence for the dyking ascent mechanism. Trans Roy Soc Edinb Earth Sci $83: 377-382$

Klimas K (2008) Geochronology and petrogenetical study of zircons from selected crystal line rocks in the eastern part of the ForeSudetic Block (in Polish with English summary). Uniwersytet Wrocławski Instytut Nauk Geologicznych, Wrocław

Kowalczyk D (2006) Petrography and tectonics of the envelope of the Strzelin intrusion (in Polish with English summary). The University of Wrocław, MS Thesis 1-57

Kruhl JH (1996) Prism- and basal-plane parallel subgrain boundaries in quartz: a microstructural geothermobarometer. J Meta Geol 14:581-589

Lopianowski S (1922) Zur Tektonik des Granitmassivs von StriegauZobten. Tektonik und Magma. Untersuchungen zur Geologie der Tiefen. Abh Preuss Geol L-A NF 89:71-92

Lorenc MW (1984) Endogenous enclosures (autoliths) as evidence of magmatic origin of the Strzelin granitoids (in Polish with English summary). Geol Sudetica 19:75-97

Matte P, Maluski H, Rajlich P, Franke W (1990) Terrane boundaries in the Bohemian Massif: results of large scale Variscan shearing. Tectonophysics 177:151-170

Mazur S, Aleksandrowski P, Kryza R, Oberc-Dziedzic T (2006) The Variscan Orogen in Poland. Geol Quart 50:89-118

Mazur S, Aleksandrowski P, Turniak K, Awdankiewicz M (2007) Geology, tectonic evolution and Late Palaeozoic magmatism of Sudetes-an overview. In: Kozłowski A, Wiszniewska J (eds) Granitoids in Poland AM Monograph 1, Warszawa, pp 59-87

Mazur S, Kröner A, Szczepański J, Turniak K, Hanžl P, Melichar R, Rodionov NV, Paderin I, Sergeev SA (2010) Single zircon U-Pb ages and geochemistry of granitoid gneisses from SW Poland: evidence for an Avalonian affinity of the Brunian microcontinent. Geol Mag 147:508-526

Morawski T, Kościówko H (1975) Granites of the Strzelin region and their contacts (in Polish). Przewodnik 47 Zjazdu PTG, Warszawa, pp 181-183

Oberc J (1966) Geology of crystalline rocks of the Wzgórza Strzelińskie Hills, Lower Silesia (in Polish with English summary). Stud Geol Pol 20:1-187

Oberc J (ed), Oberc-Dziedzic T, Klimas-August K (1988) Geological map of the Strzelin Hills (1:25 000) (in Polish). Instytut Nauk Geologicznych Uniwersytetu Wrocławskiego, Przedsiębiorstwo Geologiczne Wrocław

Oberc-Dziedzic T (1991) Geological setting of the Strzelin granitoids (in Polish with English summary). Acta Univ Wratisl Pr Geol Mineral 29:295-324

Oberc-Dziedzic T (1999) The metamorphic and structural development of gneisses and older schist series in the Strzelin Crystalline Massif (Fore-Sudetic Block, SW Poland). Mineral Soc Poland Spec Pap 14:10-21

Oberc-Dziedzic T (2007) Internal structure of the granite and tonalite intrusions in the Strzelin massif. In: Kozłowski A, Wiszniewska J (eds) Granitoids in Poland AM Monograph 1, Warszawa, pp 217-229

Oberc-Dziedzic T, Kryza R (2012) Late stage Variscan magmatism in the Strzelin Massif (SW Poland): SHRIMP zircon ages of tonalite and Bt-Ms granite of the Gęsiniec intrusion. Geol Quart $56: 225-236$

Oberc-Dziedzic T, Madej S (2002) The Variscan overthrust of the Lower Palaeozoic gneiss unit on the Cadomian basement in the Strzelin and Lipowe Hills massifs, Fore-Sudetic Block, SW Poland; is this part of the East-West Sudetes boundary? Geol Sudetica 34:39-58

Oberc-Dziedzic T, Kryza R, Klimas K, Fanning MC (2003) SHRIMP $\mathrm{U} / \mathrm{Pb}$ zircon geochronology of the Strzelin gneiss, SW Poland: evidence for a Neoproterozoic thermal event in the Fore-Sudetic Block, Central European Variscides. Int J Earth Sc (Geol Rundsch) 92:701-711

Oberc-Dziedzic T, Kryza R, Klimas K, Fanning MC, Madej S (2005) Gneiss protolith ages and tectonic boundaries in the NE part of the Bohemian Massif (Fore-Sudetic Block, SW Poland). Geol Quart 49:363-378

Oberc-Dziedzic T, Kryza R, Białek J (2010) Variscan multistage granitoid magmatism in Brunovistulicum: petrological and SHRIMP U/Pb zircon geochronological evidence from the southern part of the Strzelin Massif, SW Poland. Geol Quart 54:301-324

Oberc-Dziedzic T, Kryza R, Pin C, Madej S (2013). Variscan granitoid plutonism in the Strzelin Massif (SW Poland): petrology and age of the composite Strzelin granite intrusion. Geol Quart 57(2) (in press)

Ochnik K (2003) Tectonics of the granite in the vicinity of Strzelin. (in Polish with English summary). The University of Wrocław, MS Thesis 1-58

Oliver GJH, Corfu F, Krough TE (1993) U-Pb ages from SW Poland: evidence for a Caledonian suture zone between Baltica and Gondwana. J Geol Soc London 150:355-369

Passchier CV, Trouw AJ (2005) Microtectonics. Springer, Berlin Heidelberg

Paterson SR, Miller RB (1998) Stoped blocks in pluton: paleo-plumb bobs, viscometers, or chronometers? J Struct Geol 20:1261-1272

Paterson SR, Vernon RH, Tobisch OT (1989) A review criteria for the identification of magmatic and tectonic foliations in granitoids. J Struct Geol 11:349-363

Paterson SR, Fowler TK Jr, Schmidt KL, Yoshinobu AS, Yuan ES, Miller RB (1998) Interpreting magmatic fabric in plutons. Lithos 44:53-82

Pawley MJ, Collins WJ (2002) The development of contrasting structures during the cooling and crystallisation of a synkinematic pluton. J Struct Geol 24:469-483

Pharoah TC (1999) Palaeozoic terranes and their lithospheric boundaries within the Trans-European Suture Zone (TESZ): a review. Tectonophysics 314:17-41

Pitcher WS (1993) The nature and origin of granite. Blackie A P London, Glasgow

Price NJ, Cosgrove JW (1994) Analysis of geological structures. Cambridge University Press

Rothery E (1988) En échelon vein array development in extension and shear. J Struct Geol 10:63-71

Schulmann K, Gayer R (2000) A model for a continental accretionary wedge developed by oblique collision: the NE Bohemian Massif. J Geol Soc London 157:401-416

Smith JV (1996) En échelon sigmoidal vein arrays hosted by faults. J Struct Geol 18:1173-1179

Suess FE (1912) Die moravischen Fenster und ihre Beziehung zum Grundgebirge des Hohen Gesenke. Denkschr Österr Akad Wiss Math-Naturwiss K1 88:541-631

Suess FE (1926) Intrusionstektonik und Wandertektonik im variszischen Gebirge. Borntraeger, Berlin

Tikoff B, Teyssier C (1992) Crustal-scale, en-echelon "P-shear" tensional bridges: a possible solution to the batholic room problem. Geology 20:927-930 
Žák J, Vyhnálek B, Kabele P (2006) Is there a relationship between magmatic fabric and brittle fractures in plutons? A view based on structural analysis, anisotropy of magnetic susceptibility and thermo-mechanical modelling of the Tanvald pluton (Bohemian Massif). Phys Earth Planet Inter 157:286-310
Žák J, Verner K, Klomínský J, Chlupáčová M (2009) “Granite tectonics" revisited: insights from comparison of K-feldspar shape fabric, anisotropy of magnetic susceptibility (AMS), brittle fractures in the Jizera granite, Bohemian Massif. Int J Earth Sc (Geol Rundsch) 98:949-967 